\title{
Role Conflict in Community Corrections
}

\author{
Troy J. Allard \\ Richard K. Wortley \\ Anna L. Stewart \\ School of Criminology and Criminal Justice \\ Griffith University \\ Brisbane Qld 4111 \\ Australia \\ Authors' Note \\ The authors wish to thank the Queensland Department of Corrective Services for \\ Correspondence concerning this article should be addressed to Troy J. Allard,
} their cooperation and assistance with this research. School of Criminology and Criminal Justice, Griffith University, Brisbane 4111, Australia. Electronic mail may be sent via Internet to:

T.Allard@mailbox.gu.edu.au 


\begin{abstract}
A study was conducted to determine whether prior research had accurately conceptualised community correctional officers' experience of role conflict on the basis of officers' role preferences. It was hypothesised that officers who were welfare workers or punitive officers would experience inter-role conflict while those who attempted to combine the welfare and punitive roles (protective agents) would experience intra-role conflict and role ambiguity. Furthermore, an exploration of how inter-role conflict, intra-role conflict, role ambiguity, and officer's role preferences were related to occupational burnout was conducted. It was found in this study that officers preference for the role of welfare worker, protective agent, or punitive officer were not related to the level of inter-role conflict, intra-role conflict, or role ambiguity experienced by officers. Officers' role preferences were not related to burnout. Inter-role conflict and intra-role conflict were associated with emotional exhaustion. These findings call into question the whole tradition in the community corrections literature of inferring role conflict from officers' role preferences and necessitate that the whole issue of whether officers experience role conflict be revisited by employing direct measures of role conflict.
\end{abstract}

Key Words: Community Corrections, Role Conflict, Occupational Burn-out. 


\section{ROLE CONFLICT IN COMMUNITY CORRECTIONS}

Role conflict is a perennial issue in community corrections and has received considerable academic attention since the 1960s. While the commonsense assumption that officers experience role conflict may be somewhat less applicable in light of the recent international trend towards a get tough approach to offender management, the roles performed by community correctional officers within the Queensland context are such that they may plausibly be in conflict with one another. In Queensland, officers are responsible for the management of offenders on a range of community based orders including probation, parole, intensive correction, and home detention orders. Most officers work exclusively in the community and only a small proportion work in custodial centres. The management of offenders involves two distinct roles.

On the one hand, officers perform a therapist or welfare role and must focus on the offender and the personal and social problems that are believed to explain their offending behaviour and determine appropriate case management plans to facilitate behavioural and attitudinal change (Callison, 1983; Cressey, 1965; Zald, 1962). In order to actively engage offenders to participate in and follow through with their case management plans, it is essential for officers to form effective ties with offenders through a warm, neutral, non-judgemental relationship built on understanding, acceptance and respect (Blumberg, 1979; Clear \& Latessa, 1993; Diana, 1970; Dressler, 1971; Leger \& Stratton, 1977; Speiss \& Johnson, 1980; Stanley, 1976).

On the other hand, officers perform a control or enforcement role and must ensure that offenders comply with the conditions of their order to ensure judicial and community confidence in community based supervision (Barnett \& Gronewold, 1970; 
Clear \& Latessa, 1993; Dressler, 1971; Hardman, 1960; Harris, 1980; Klockars, 1972; Weiner \& Hess, 1987; Worrall, 1977). Typically, officers must enforce numerous conditions such as ensuring that the offender: (i) complies with the law, (ii) reports as directed, (iii) notifies of any change of residence or employment, (iv) stays within the jurisdiction, and (v) complies with all reasonable directions. Additionally, officers must ensure that additional requirements ordered by the court or board are attended to, such as ensuring that offenders attend specified programs, pay restitution or compensation, or abstain from alcohol or drugs (Blumberg, 1979; Dressler, 1971; Stanley, 1976).

The apparent incompatibility of the welfare and enforcement roles has resulted in considerable speculation regarding the importance of role conflict in community corrections. While some have argued that officers can provide "supportive surveillance" or "caring authority", most maintain that the welfare and enforcement philosophies underpinning the officers' role are mutually exclusive and have suggested models which have emphasised welfare or enforcement or which have attempted to separate the two functions (Barkdull, 1976; Bryant, Coker, Estlea, Himmel, \& Knapp, 1978; Griffiths, 1991; Harris, 1980; Singer, 1980). Such arguments are typically based on the premise that the officers' welfare and enforcement roles necessarily impact on one another and that emphasis on one role inevitability reduces the ability of officers to perform the other role (Garabedion, 1959; Hepburn \& Albonetti, 1980; Pogrebin, 1978). Thus, the officers' enforcement role impedes the ability of officers to perform their welfare role by reducing the accuracy of information required to accurately assess the offender's circumstances and needs (Klockars, 1972; Newman, 1970; Stanley, 1976). 
Despite the existence of an abundance of theoretical arguments supporting the proposition that community correctional officers experience role conflict, the exact nature of this conflict remains unclear (Clear \& Latessa, 1993; Lanningham, Taber, \& Dimants, 1966; Sigler, 1988; Speiss \& Johnson, 1980). Most prior research has conceptualised role conflict by placing paramount importance on officers’ role preferences (Donnellian \& Moore, 1979; Glaser, 1964; Miles, 1965; Sigler \& McGraw, 1984; Sluder \& Reddington, 1993; Studt, 1978). That is, studies have typically asked officers to rank the importance of various activities or have asked officers to locate themselves, other officers, and their perception of official purposes along a continuum between the treatment and enforcement philosophies (Donnellian \& Moore, 1979; Glaser, 1964; Lanningham, Taber, and Dimant, 1966; Miles, 1964; Sigler \& McGraw, 1984). Results have been interpreted in one of three ways. Firstly, researchers have viewed officers' differing preferences for welfare and enforcement as evidence that they experience role conflict (Sigler, 1988). Secondly, researchers have viewed officers’ equal preference for care and enforcement as evidence that they experience role conflict (Clear \& Latessa, 1993). Thirdly, researchers have viewed divergence between officers’ role preferences and their perceptions of official purposes as evidence that they experience role conflict (Speiss \& Johnson, 1980).

Once 'evidence' of role conflict has been found, it is argued that officers respond to this role conflict by adopting one of three roles (Dressler, 1971; Klockars, 1972; Ohlin, Pivin, \& Pappenfort, 1959; Sigler, 1988). Welfare workers aim to introduce offenders to a better way of life by motivating constructive patterns of behaviour through the provision of support and guidance. Protective agents view their role as fulfilling a 
dual responsibility to the offender and the community and thus aim to reconcile the therapist and police functions. The final role that may be adopted by officers is that of the punitive officer whereby officers view their role as enforcing compliance with legal and organisational requirements.

Despite these theoretically proposed ways that officers may respond to role conflict, it is still unclear how role preference is related to role conflict. Given the nature of the role performed by officers and the broad discretionary powers they possess, officers' role preferences are undoubtedly an interesting phenomenon to study in its own right. But whether and how role preference is related to role conflict is yet to be determined. It is clearly possible that officers, with differing role preferences, do not experience role conflict as they ultimately make sense of the competing demands of welfare and enforcement. Indeed, studies that have examined whether officers experience role conflict using field research have found that most officers are able to perform both roles and develop an adaptive role, providing the welfare and enforcement roles as the circumstances dictate (Clear \& Latessa, 1993; Erwin \& Bennett, 1987; Hardyman, 1988; McCleary, 1978; Studt, 1978; Whitehead, 1990).

To date, there are few studies that have employed direct measures of role conflict when investigating community correctional officers. Studies that have employed a direct measure have broadly conceptualised role conflict as the degree to which officers’ expectations of their role are incompatible with the reality of their role (Holgate \& Clegg, 1991; Whitehead, 1987; Whitehead \& Lindquist, 1985). These studies have focused their attention on the effect that role conflict has on officers. Of the various outcome 
measures that have been examined, occupational burnout has been the most frequently examined phenomenon.

Occupational burnout is a multifaceted phenomenon characterised by emotional exhaustion, depersonalisation, and feelings of reduced personal accomplishment (Lee \& Ashforth, 1990; Maslach, 1982). Emotional exhaustion is the key component in occupational burnout and involves the depletion of one's emotional resources and feelings of being over-extended (Cordes \& Dougherty, 1993; Greenglass, 1991; Maslach \& Jackson, 1981, 1986; Rhoads, 1994; Whitehead \& Lindquist, 1986). Emotional exhaustion has been associated with numerous stress-related outcomes including tension, anxiety, physical fatigue, and insomnia in addition to a deterioration in the quality of care provided by staff, low morale, absenteeism, high turnover, increased use of drugs and alcohol, and increased marital and family problems (Beemsterboer \& Baum, 1984; Maslach \& Jackson, 1981; Perlman \& Hartman, 1982; Pines \& Maslach, 1978, 1980). Depersonalisation adds an interpersonal dimension and is a defensive coping mechanism whereby one develops a negative or callous attitude towards the clients with whom one works in order to minimise emotional exhaustion (Greenglass, 1991; Lee \& Ashforth, 1990; Whitehead \& Lindquist, 1986). The final component of occupational burnout is feelings of reduced personal accomplishment whereby one experiences a decline in his or her feelings of competence and successful achievement in working with people (Greenglass, 1991; Rhoads, 1994).

Studies involving community correctional officers have found that role conflict was related to emotional exhaustion (Holgate \& Clegg, 1991), the impersonal treatment of offenders (Whitehead, 1987; Whitehead \& Lindquist, 1985), and greater occupational 
burnout (Whitehead \& Lindquist, 1985). While these findings lend support to the validity of the role conflict scale, the broad conceptualisation of role conflict adopted in these studies did not allow for a full exploration of how role conflict was related to occupational burnout. More importantly, these studies did not explore the fundamental question of how role conflict was related to role preference.

The present study will more precisely conceptualise role conflict on the basis of two distinct types. Inter-role conflict entails a conflict where the individual perceives others as being responsible for the incompatibility, which might occur when an individual has to perform roles that require incompatible behaviour or when there are conflicting organisational expectations and demands (Schwab, Iwanicki, \& Pierson, 1983). In contrast, intra-role conflict entails a conflict where the individual perceives him/herself as being responsible for the incompatibility as occurs when officers have to violate personal values or standards or when officers perceive their role as being beyond their capabilities, time constraints, or available resources (Schwab, Iwanicki, \& Pierson, 1983). Additionally, the present study will examine role ambiguity which is the extent that an individual is uncertain about their duties, authority, and allocation of time, as based on unclear guidelines, directives, and policies.

On the basis of this conceptualisation, a number of hypothesises are conceivable. Firstly, it is likely that officers who prefer to perform the role of welfare worker or punitive officer will experience inter-role conflict. This is because officers who are certain about how they should appropriately perform their role are likely to externalise blame for any conflict that they experience. In essence, these officers know how they should perform their role and any conflict that they experience will be blamed on the 
influence of external forces. Secondly, it is conceivable that officers who prefer to perform the role of protective agent will experience intra-role conflict and role ambiguity. This is because officers who attempt to perform both the welfare and punitive aspects of their role may be uncertain about how to balance two apparently incompatible roles. Further, officers who attempt to perform both roles may internalise blame for any conflict that they experience on the basis of being unable to adequately perform the dual roles prescribed by the organisation. Finally, this study will explore how inter-role conflict, intra-role conflict, role ambiguity, and officer's role preferences are related to the occupational burnout constructs.

\section{METHOD \\ Participants}

A total of 70 community correctional officers located throughout Brisbane (Australia) were approached and asked to complete questionnaires. Of these, 55 questionnaires were returned. The number who responded thus represented $78.57 \%$ of officers approached. Since there are 248 community correctional officers throughout Queensland, this represented 22\% of the total population. The sample size was necessarily restricted by the Queensland Department of Corrective Services due to concerns about the amount of time that officers would need to spend filling in the questionnaires and the impact that this may have on officers' caseloads. Nevertheless, several factors indicated that the sample was representative of the population. Most of the officers in the sample (69.1\%) and in the population $(70.2 \%)$ were female. The officers in the sample were slightly younger (range $=22$ to 58 years of age, $M=37.82$ 
years, $S . D=14.86$ ) than officers in the general population (range $=20$ to 71 years of age, $M=41.04 ; S . D=12.17)$. As with the population, most participants were community correctional officers (80\%) as opposed to senior community correctional officers (20\%) and all were responsible for supervising offenders on a range of orders including Probation Orders, Intensive Corrections Orders, and Parole Orders. Officers had up to 23 years experience $(M=5.78, S . D=6.56)$.

\section{Materials}

\section{$\underline{\text { Role preference }}$}

Officers’ role preferences were assessed using Fulton, Stichman, Travis, and Latessa’s (1997) Subjective Role Scale. The scale required officers to locate themselves along a six point semantic differential between 11 pairs of words. For example, officers were required to indicate their primary obligation or concern as rehabilitation or enforcement, advocate or supervisor, and intervention or surveillance. Using this scale, officers were placed along a single continuum from 11 to 66 . Lower scores indicated that officers preferred the role of welfare worker while higher scores indicated that officers preferred the role of punitive officer. Scores approaching the middle indicated that officers were protective agents in that they preferred to perform both roles.

\section{$\underline{\text { Role conflict and role ambiguity }}$}

Role conflict and role ambiguity were assessed using Rizzo, House, and Lirtzman’s (1970) Role Conflict and Role Ambiguity Scale. The scale required officers to indicate their level of agreement with statements along a five point Likert scale 
(ranging from strongly disagree to strongly agree). Although the original Role Conflict Subscale consisted of eight items, these items were split on the basis of the criteria outlined by Schwab, Iwanicki, and Pierson (1983). Thus, four items were used to assess inter-role conflict and four items were used to assess intra-role conflict with higher scores indicative of greater conflict. Both inter-role and intra-role conflict assess divergence between the individual's expectations of their role and the reality of their role. The difference between the two constructs lies in the attribution of blame. Inter-role conflict entails the attribution of blame for incompatible roles to others while intra-role conflict entails the attribution of blame for incompatible roles to ones-self.

The Role Ambiguity Subscale consisted of six items and scores were reversed so that higher scores indicated higher ambiguity. The role ambiguity construct measured the extent that an individual was uncertain about their duties, authority, and allocation of time, as based on unclear guidelines, directives, and policies. Thus, the role ambiguity sub-scale assessed the level of uncertainty that officers experienced in performing their role while the inter-role and intra-role conflict sub-scales assessed the degree to which an individual's expectations of their role were incompatible with the reality of the role and whether the cause of this incompatibility were attributed to others or ones-self. Studies have consistently found the Role Conflict and Role Ambiguity Subscales to be a highly reliable ( $\alpha=>$.78 for both scales) and valid instrument (Gonzalez-Roma \& Lloret, 1989; House, Schuler, \& Levanoni, 1983; Jackson \& Schuler, 1985; Kelloway \& Barling, 1990; Rizzo, House, \& Lirtzman, 1970; Rosenkrantz, Luthans, \& Hennessey, 1983). Schwab, Iwanicki, and Pierson (1983) found the Intra-Role Conflict Subscale and the Inter-Role Conflict Subscale to be highly reliable ( $\alpha=>.77$ for both scales). 


\section{$\underline{\text { Occupational burnout }}$}

Occupational burnout was assessed using the Maslach Burnout Inventory (Maslach \& Jackson, 1981). The inventory required officers to indicate how often they felt a particular way about their job by responding to 22 items along a six point Likert scale (ranging from never to everyday) which yielded three scores reflecting emotional exhaustion, depersonalisation, and personal accomplishment. Officer's scores on the Personal Accomplishment Subscale were reversed so that high levels of burnout were reflected by high scores on each subscale.

Maslach and Jackson (1986) demonstrated that emotional exhaustion $(\alpha=.90)$, depersonalisation ( $\alpha=.79)$, and personal accomplishment $(\alpha=.71)$ were reliable measures. Furthermore, Maslach and Jackson (1986) reported good test-retest reliabilities conducted over a four week period: emotional exhaustion $(\alpha=.82)$, depersonalisation $(\alpha=.60)$, and personal accomplishment $(\alpha=.80)$. The inventory has also been shown to be valid and to discriminate successfully from other psychological measures (Green \& Walkey, 1988; Iwanicki \& Schwab, 1981; Jackson, Turner, \& Brief, 1987; King \& Beehr, 1983; Maslach \& Jackson, 1981, 1986)

\section{Procedure}

In conjunction with the Department of Corrective Services Research Committee, the researchers selected and attended ten area offices located throughout Brisbane in order to distribute questionnaires. Participants were approached during staff meetings and while most officers chose to complete and return questionnaires on-the-spot, others chose to complete and return questionnaires in the self-addressed envelope provided. In 
either case, anonymity was ensured via immediately separating informed consent forms from questionnaires upon receipt.

\section{RESULTS}

Cronbach's alpha coefficients were computed to establish the reliability of each subscale and Pearson product-moment correlations were computed to determine the interrelatedness of each variable under consideration. As can be seen from Table 1, reliabilities ranged from $\alpha=.62$ to $\alpha=.92$. Thus, the reliabilities were considered adequate and within the accepted parameters for social science research. As can be seen from the correlation matrix presented in Table 2, the demographics were highly interrelated. The only scale related to any of the demographic variables was the Subjective Role Scale. Older and more experienced officers preferred to perform a welfare role while younger and less experienced officers preferred to perform a more punitive role. The three constructs drawn from the Role Conflict and Role Ambiguity Scale were highly inter-related as were the three constructs drawn from the Maslach Burnout Inventory. Both forms of role conflict were related to emotional exhaustion.

Table 1 about here.

Table 2 about here. 
Three regression analyses were performed to determine whether there was a difference in the levels of intra-role conflict, inter-role conflict, or role ambiguity experienced by officers (dependent variables) on the basis of their role preference (predictor variable). Results of the regression analyses showed that role preference was not significantly related to intra-role conflict $(F(1,53)=.49, p=.49)$, inter-role conflict $(F(1,53)=2.29, p=.14)$, or role ambiguity $(F(1,53)=1.09, p=.30)$. However, because a curvilinear relationship was hypothesised between role preference and the three dependent variables (ie: it was expected that officers who preferred the care or punitive role would experience inter-role conflict and officers who preferred both roles would experience intra-role conflict and role ambiguity), the analysis was also performed using the quadratic term for the role preference variable. Again, however, no significant relationships were found for either intra-role conflict $(F(52)=.24, p=.79)$, inter-role conflict $(F(52)=1.24, p=.30)$, or role ambiguity $(F(52)=.54, p=.59)$. Thus, it can be concluded that there is neither a straight line nor curvilinear relationship between role preference on the one hand, and role ambiguity, intra-role conflict, and inter-role conflict on the other.

The final research question sought to explore how intra-role conflict, inter-role conflict, role ambiguity, and officers' role preferences were related to their experience of occupational burnout. In order to examine these relationships, a multiple regression analysis was performed. The independent variables were the levels of emotional exhaustion, depersonalisation, and reduced personal accomplishment experienced by 
officers. The dependent variables were the levels of intra-role conflict, inter-role conflict, and role ambiguity experienced by officers as well as officers' role preference scores. In this analysis, role preference was used as a continuous variable as it had already been established that there was no curvilinear relationship between officers role preferences (categorised as welfare worker, protective agent, and punitive officer) and the level of intra-role conflict, inter-role conflict, or role ambiguity that officers experienced. No demographic variables were included in the analysis due to an absence of significant correlations between demographics and the variables of interest.

Results of the multiple regression analysis indicated a significant main effect for emotional exhaustion $(F(4,48)=3.12, p<.05)$. As can be seen from Table 3, intrarole conflict and inter-role conflict were independently related to the level of emotional exhaustion experienced by officers. There was no relationship between intra-role conflict or inter-role conflict and the level of depersonalisation or reduced personal accomplishment experienced by officers. Similarly, role ambiguity and officer's role preference scores were not related to emotional exhaustion, depersonalisation, or reduced personal accomplishment. Thus, officers who experienced higher levels of intra-role conflict or inter-role conflict also tended to experience higher levels of emotional exhaustion.

Table 3 about here. 


\section{DISCUSSION}

This study was conducted to determine whether prior research had accurately conceptualised role conflict on the basis of officers' role preferences. It was found that officers’ preference for welfare worker, protective agent, or punitive officer were not related to the level of intra-role conflict, inter-role conflict, or role ambiguity experienced by officers. However, officers experiencing intra-role conflict and inter-role conflict were found to experience greater levels of emotional exhaustion. The level of role ambiguity experienced by officers and officers’ role preference scores were not related to the level of emotional exhaustion experienced by officers. Officers' experience of intra-role conflict, inter-role conflict, role ambiguity, and officer's role preference scores were not found to be related to the level of depersonalisation or reduced personal accomplishment experienced by officers.

The present research was prompted by the reliance of previous research on officers' role preferences in assessing whether or not officers experienced role conflict. Thus, while there is a considerable amount of research examining officers' role preferences, the implications of this research in terms of whether or not officers experience role conflict is a matter of conjecture. The present findings call into question the tradition in the community corrections literature of inferring role conflict from officers’ role preferences. Despite divergent views amongst officers regarding whether they viewed their role as welfare worker, protective agent, or punitive officer, it appears that these differing views regarding the appropriate role that should be performed by officers were inconsequential or officers were able to resolve any tension that occurred. 
Indeed, the impact of divergent views regarding the appropriate role of community correctional officers on officers may be minimal as the clear majority of officers preferred the role of protective agent. Most officers in the present study preferred to perform both the welfare and enforcement roles, and as these officers did not experience role conflict or occupational burnout, they were able to successfully manage and combine the welfare and enforcement roles. Even officers who had an extreme preference for a welfare or punitive role were able to resolve any tension and did not experience either form of role conflict or occupational burnout. These findings challenge the commonly held assumption that the role performed by community correctional officers is plagued by conflict.

The finding that officers who experienced intra-role conflict or inter-role conflict also tended to experience emotional exhaustion accords with previous research findings. This research, however, differed from previous research by examining two distinct forms of role conflict. It appears that whether officers view themselves or others as being responsible for role conflict is inconsequential as both affect officers by increasing their emotional exhaustion. While this finding supports the proposition that the level of role conflict experienced by officers does have an effect on officers, it does not provide sufficient evidence to support the proposition that the role performed by officers is plagued by conflict.

Despite the limitations of the present study, including the use of a purposive and relatively small sample, the findings suggest that the issue of whether community correctional officers experience role conflict should be revisited. Clearly, there is little empirical evidence to support the contention that officers experience role conflict as a 
result of their role preference. Future research should accurately conceptualise role conflict and not simply infer that officers experience role conflict on the basis of community correctional officers having differing role preferences. One strategy that might be useful is the development of an occupationally specific questionnaire focusing on the tensions between the welfare and enforcement aspects of the officers' role. Such a questionnaire should differentiate between internal or personally based conflicts (intrarole conflict) and external or organisationally based conflicts (inter-role conflict). This approach appeared valid in the present study, as both forms of conflict were related to emotional exhaustion. Such an approach would enable a more sophisticated understanding of the tensions faced by community correctional officers and clarification of the issues surrounding whether community correctional officers experience role conflict. 


\section{REFERENCES}

Barkdull, W. (1976). Probation: Call it control - and mean it. Federal Probation, 40, 3-8.

Barnett, J., \& Gronewold, D. (1970). Confidentiality of the pre-sentence report. In R. Carter and L. Wilkins (Eds.), Probation and parole: Selected readings (pp. 98 105). New York: John Wiley \& Sons.

Beemsterboer, J., \& Baum, B. (1984). Burnout: Definitions and health care management. Social Work in Health Care, 10, 97-109.

Blumberg, A. (1979). Criminal justice: Issues and ironies $\left(2^{\text {nd }}\right.$ ed.). New York: New Viewpoints.

Bryant, M., Coker, J., Estlea, B., Himmel, S., \& Knapp, T. (1978). Sentenced to social work?. Probation Journal, 24, 110-114.

Callison, H. (1983). Introduction to community-based corrections. New York: McGraw-Hill Book Company.

Clear, T.R., \& Latessa, E.J. (1993). Probation officer roles in intensive surveillance versus treatment. Justice Quarterly, 10, 441-462. 
Cordes, C., \& Dougherthy, T. (1993). A review and integration of research on job burnout. Academy of Management Review, 18, 621-656

Cressey, D. (1965). Prison organisations. In J. Marsh (Ed.). Handbook of organisations (pp. 1023-1070). Chicago: Rand McNally.

Diana, L. (1970). What is probation. In R. Carter and L. Wilkins (Eds.). Probation and Parole: Selected Readings (pp. 39-56). New York: John Wiley \& Sons.

Donnellian, M., \& Moore, H. (1979). Rehabilitation and protection: The goals and orientations of probation and parole officers. Offender Rehabilitation, 3, 207-218.

Dressler, D. (1971). Practice and theory of probation and parole $\left(2^{\text {nd }}\right.$ ed.). New York: Columbia University Press.

Erwin, B.S., \& Bennett, L.A. (1987). New dimensions in probation: Georgia's experience with intensive probation supervision. Washington: National Institute of Justice.

Fulton, B., Stichman, A., Travis, L., \& Latessa, E. (1997). Moderating probation and parole officer attitudes to achieve desired outcomes. Prison Journal, 77, 295-312. 
Garabedion, P. (1959). Western penitentiary: A study in social organisation. PhD Dissertation: University of Washington.

Gonzalez-Roma, V., \& Lloret, S. (1989). Construct validition of Rizzo et al.’s (1970) role conflict and ambiguity scales: A multisample study. Applied Psychology: An International Review, 47, 535-545.

Glaser, D. (1964). The effectiveness of a prison and parole system. Indianapolis: The Bobbs-Merrill Company.

Green, D., \& Walkey, F. (1988). Confirmation of the three factor structuring of the Maslach Burnout Inventory. Educational and Psychological Management, 48, 579585.

Greenglass, E. (1991). Burnout and gender: Theoretical and organisational implications. Canadian Psychology, 32, 562-572.

Griffiths, W. (1991). A new probation service. Probation Journal, 29, 98-100.

Hardman, D. (1960). The function of the probation officer. Federal Probation, 24, 3-10. 
Hardyman, P. (1988). No frills: A study of probation resources, activities, and outcome. Doctorial Dissertation, Rutgers University.

Harris, R. (1980). A challenging service: The case for separating care and control in probation practice. British Journal of Social Work, 10, 163-184.

Hepburn, J., \& Albonetti, C. (1980). Role conflict in correctional institutions: An empirical examination of the treatment-custody dilemma among correctional staff. Criminology, 17, 445-459.

Holgate, A.M., \& Clegg, I.J. (1991). The path to probation officer burnout: New dogs, old tricks. Journal of Criminal Justice, 19, 325-337.

House, R., Schuler, R., \& Levanoni, E. (1983). Role conflict and ambiguity scale: Reality or artifacts. Journal of Applied Psychology, 68, 334-337.

Iwanicki, E., \& Schwab, R. (1981). A cross validation study of the MBI. Educational and Psychological Measurement, 41, 1167-1174.

Jackson, S., \& Schuler, R. (1985). A meta-analyses and conceptual critique of research on role ambiguity and role conflict in work settings. Organisational Behaviour and Human Decision Processes, 36, 16-78. 
Role conflict in Community Corrections

Jackson, S., Turner, J., \& Brief, A. (1987). Correlates of burnout among public service lawyers. Journal of Occupational Behaviour, 8, 339-349.

Kelloway, E.K., \& Barling, J. (1990). Item content versus item wording: Disentangling role conflict and role ambiguity. Journal of Applied Psychology, 75, 738742.

King, L., \& Beehr, T. (1983). Therapist burnout: Reliability and validity of the Maslach Burnout Inventory. In C. Maslach and E. Jackson (Eds.). Maslach Burnout Inventory: Manual ( $2^{\text {nd }}$ ed.). Oalo Alto, CA: Consulting Psychologists Press.

Klockars, C. (1972). A theory of probation supervision. Journal of Criminal Law, Criminology, and Police Science, 63, 550-557.

Lanningham, D., Taber, M., \& Dimants, R. (1966). How adult probation officers view their job responsibilities. Crime and Delinquency, 12, 97-108.

Lee, R.T., \& Ashforth, B.E. (1990). On the meaning of Maslach’s three dimensions of burnout. Journal of Applied Psychology, 75, 743-747.

Leger, R., \& Stratton, J. (1977). Correctional institutions as complex organisations. In R. Leger and J. Stratton (Eds.). The Sociology of Corrections: A Book of Readings (pp. 1-7). New York: John Wiley. 
Maslach, C. (1982). Burnout: The cost of caring. Englewood Cliffs, NJ: Prentice Hall.

Maslach, C., \& Jackson, S.E. (1981). The measurement of experienced burnout. Journal of Occupational Behaviour, 2, 99-113.

Maslach, C., \& Jackson, S. (1986). Maslach burnout inventory: Manual (2 ${ }^{\text {nd }}$ ed.). Palo Alto, CA: Consulting Psychologists Press.

McCleary, R. (1978). Dangerous men: The sociology of parole. California: Sage.

Miles, A. (1965). The reality of the probation officer's dilemma. Federal Probation, 29, 18-23.

Newman, C. (1970). Concepts of treatment in probation and parole supervision. In R.Carter and L. Wilkins (Eds.). Probation and Parole: Selected Readings (pp. 279289). New York: John Wiley \& Sons.

Ohlin, L.E., Pivin, H., \& Pappenfort, D.M. (1959). Major dilemmas of the social worker in probation and parole. National Probation and Parole Association Journal, 2, 211-225. 
Perlman, B., \& Hartman, E.A. (1982). Burnout: Summary and future research. Human Relations, 33, 283-305.

Pines, A., \& Maslach, C. (1978). Characteristics of staff burn-out in mental health settings. Hospital and Community Psychiatry, 29, 233-237.

Pines, A., \& Maslach, C. (1980). Combatting staff burn-out in a day care center: A case study. Child Care Quarterly, 9, 5-16.

Pogrebin, M. (1978). Role conflict among correctional officers in treatment orientated correctional institutions. International Journal of Offender Therapy and Comparative Criminology, 22, 149-155.

Rhoads, G. (1994). Behavioural psychological consequences of boundary spanning on customer service representatives. Journal of Marketing Research, 31, 558570.

Rizzo, J.R., House, R.J., \& Lirtzman, S.I. (1970). Role conflict and ambiguity in complex organisations. Administrative Service Quarterly, 15, 150-163. 
Rosenkrantz, S.A., Luthans, F., \& Hennessey, H.W. (1983). Role conflict and ambiguity scales: An evaluation of psychometric properties and the role of social desirability response bias. Educational and Psychological Measurement, 43, 957-970.

Schwab, R., Iwanicki, E., \& Pierson, D. (1983). Assessing role conflict and role ambiguity: A cross validation study. Educational and Psychological Measurement, 43, 587-593.

Sigler, R. (1988). Role conflict for adult probation and parole officers: Fact or Myth. Journal of Criminal Justice, 16, 121-129.

Sigler, R., \& McGraw, B. (1984). Adult probation and parole officers: Influence of their weapons, role perceptions, and role conflict. Criminal Justice Review, 9, 28-32.

Singer, L. (1980). Supportive surveillance: Probation as discipline. International Journal of the Sociology of Law, 8, 251-275.

Sluder, R.D., \& Reddington, F.P. (1993). An empirical investigation of the work ideologies of juvenile and adult probation officers. Journal of Offender Rehabilitation, 20, 115-137. 
Speiss, C., \& Johnson, E. (1980). Role conflict and ambiguity in probation: Structural sources and consequences in West Germany. International Journal of Comparative and Applied Criminal Justice, 4, 179-189.

Stanley, D.T. (1976). Prisoners among us: The problem with parole. Washington: The Brookings Institution.

Studt, E. (1978). Surveillance and service to parole. Washington: United Nations Department of Justice, National Institute of Corrections.

Weiner, I., \& Hess, A. (1987). Handbook of forensic psychology. New York: John Wiley \& Sons.

Whitehead, J.T. (1987). Probation officer job burnout: A test of two theories. Journal of Criminal Justice, 15, 1-16.

Whitehead, P. (1990). Community supervision of offenders: A new model of probation. Aldershot: Avebury.

Whitehead, J.T., \& Lindquist, C.A. (1985). Job stress and burnout among probation/parole officers: Perceptions and causal factors. International Journal of Offender Therapy and Comparative Criminology, 29, 109-119. 
Whitehead, J.T., \& Lindquist, C.A. (1986). Correctional officer job burnout: A path model. Journal of Research in Crime and Delinquency, 23, 23-42.

Worrall, A. (1977). From advice, assist and befriend to confront, control and monitor. Punishment in the Community: The Future of Criminal Justice (pp. 63-77). London: Longman.

Zald, M. (1962). Power balance and staff conflict in correctional institutions. Administrative Science Quarterly, 6, 22-49. 
Role conflict in Community Corrections

Table 1: Means, Cronbach’s Alpha's, and Standard Deviations:

\begin{tabular}{llccc}
\hline Scale & Subscale & Mean & $\alpha$ & S.D \\
\hline Subjective Role Scale & Subjective Role Scale & 35.54 & .80 & 6.71 \\
\hline Role Conflict and Role Ambiguity & Intra-Role Conflict & 12.87 & .62 & 3.01 \\
& Inter-Role Conflict & 11.96 & .71 & 3.04 \\
& Role Ambiguity & 14.18 & .75 & 3.37 \\
& Emotional Exhaustion & 19.01 & .92 & 11.37 \\
\hline Occupational Burnout & Depersonalisation & 7.29 & .73 & 5.78 \\
& Reduced Personal & 12.18 & .78 & 6.39 \\
& Accomplishment & & & \\
\hline
\end{tabular}


Role conflict in Community Corrections

Table 2: Correlation Matrix

\begin{tabular}{|c|c|c|c|c|c|c|c|c|c|}
\hline & EXP & AGE & SEX & SRS & INTRA & INTER & RA & $\mathrm{EE}$ & DEP \\
\hline AGE & .50 & & & & & & & & \\
\hline SEX & -.42 & -.15 & & & & & & & \\
\hline SRS & -.33 & -.30 & .16 & & & & & & \\
\hline INTRA & .17 & .04 & -.06 & -.10 & & & & & \\
\hline INTER & .12 & .05 & -.24 & -.20 & .57 & & & & \\
\hline RA & .01 & -.01 & -.16 & -.14 & .38 & .50 & & & \\
\hline $\mathrm{EE}$ & .19 & -.14 & -.06 & .14 & .37 & .34 & .07 & & \\
\hline DEP & -.09 & -.20 & -.11 & .16 & .17 & .14 & .17 & .60 & \\
\hline RPA & -.05 & -.18 & -.01 & .11 & .25 & .03 & .03 & .28 & .34 \\
\hline
\end{tabular}

Note: Bold indicates $p<.05$

Key:

EXP - Experience

SRS - Subjective Role Scale

INTRA - Intra-Role Conflict

INTER - Inter-Role Conflict

RA - Role Ambiguity

EE - Emotional Exhaustion

DEP - Depersonalisation

RPA - Reduced Personal Accomplishment 
Role conflict in Community Corrections

Table 3: Multiple Regression Analysis

\begin{tabular}{llccc}
\hline Independent Variable & Dependent Variable & $d f$ & Mean & $F$ \\
& & Square \\
\hline Emotional Exhaustion & Intra-Role Conflict & 1 & 46.39 & $5.78^{*}$ \\
& Inter-Role Conflict & 1 & 53.78 & $6.28^{*}$ \\
& Role Ambiguity & 1 & .56 & .05 \\
& Role Preference & 1 & 4.70 & .10 \\
\hline
\end{tabular}

$*=p<.05$ 